\title{
CANNIBALISM AND PERFORMANCE EVALUATION OF HYBRIDS BETWEEN Clarias batrachus AND Clarias gariepinus
}

\section{Samuel Olabode Olufeagba, Victor Tosin Okomoda*}

Department of Fisheries and Aquaculture, University of Agriculture Makurdi, Nigeria

${ }^{*}$ Corresponding Author, Email: okomodavictor@yahoo.com

\section{ARTICLE INFO}

Received: 16 February 2016

Received in revised form: 14 April 2016

Accepted: 18 May 2016

Available online: 3 June 2016

\begin{abstract}
Cannibalism is an important characteristic of African catfish that significantly reduces the number of stocked fish at harvest. This study evaluates the effect of reciprocal hybridization of Clarias batrachus and Clarias gariepinus on cannibalism and growth performance of their progenies in an indoor rearing system. The result obtained reveals excellent performance of hybrids of $C$. gariepinus $\delta$ and $C$. batrachus $q$ over the purebreds in terms of growth. However, the reciprocal hybrids between C. gariepinus $q$ and $C$. batrachus $\hat{\partial}$ all died few hours after hatching. Cannibalism was significantly reduced in the crosses between $C$. gariepinus of and C. batrachus $o$ with $100 \%$ survival after five months of culture. Hence, this could be exploited in commercial production of catfish to reduce cannibalism and increase harvest size of fish farmers.
\end{abstract}

Olufeagba, S. O., Okomoda, V. T. (2016): Cannibalism and performance evaluation of hybrids between Clarias batrachus and Clarias gariepinus. Croatian Journal of Fisheries, 74, 124-129. DOI: 10.1515/cjf-2016-0019.

\section{INTRODUCTION}

Hybridization is a short-term method of producing improved desirable heterosis (hybrid vigor) by crossing related species. It is expected that hybridization between $C$. gariepinus and $C$. batrachus will be successful as they both belong to the same family, Clariidae, and have similar chromosomal features as reported by Teugels (1986). C. batrachus has poor growth rate and low fecundity. They, however, have good taste with therapeutic uses which makes them possess high economic value (Sahoo et al., 2003). The poor growth has made this species less attractive as an aquaculture candidate. $C$. gariepinus, on the other hand, has high fecundity and good growth performance but is highly cannibalistic.

Attempts have been made to hybridize $C$. gariepinus with $C$. batrachus (Sahoo et al., 2003; Rahman et al., 1995), and with other species like Heterobranchus longifilis (Legendre et al.,
1992; Ataguba et al., 2010). Other reported hybridizations involved the crosses between female C. macrocephalus and male C. gariepinus (Jantrarotai, 1993), and between C. gariepinus and H. longifilis (Madu and Ita, 1991, Tober et al., 1995) to mention but a few. Positive heterosis has been reported in many hybridization trials involving $C$. gariepinus. However, despite the numerous literatures on the subject matter, little is known about cannibalism rate of hybrids from the crosses of these catfishes.

The concept of cannibalism is very important in fisheries research as it determines the final number of fish at harvest. In many fishes, activities such as aggression, territorial behavior and cannibalism result in skin lesions, fin damage and eventually death in extreme cases. Cannibalism has been defined as the act of one individual of a species consuming all or part of another individual of the same species as food (Boeuf and le Bail, 1999). It is a common ecological 
interaction in the animal kingdom and has been recorded for more than 1500 species (Mason, 1991). Cannibalism does not occur only because of extreme food shortages or artificial conditions, but as a natural condition in a variety of species (Almazán Rueda, 2004). Aggressive behavior is usually the bedrock of cannibalism in many fish species and takes a lot of time to quantify. Cannibalism requires a lot of energy which otherwise could have been used for growth (Hecht and Uys, 1997). Hence, aggression and cannibalism do not only result in stock losses (death) but also reduced food conversion efficiency and slower growth. This study is designed to evaluate cannibalism and performance of reciprocal hybrids between $C$. gariepinus and $C$. batrachus.

\section{MATERIALS AND METHODS}

\section{Induced breeding}

One female and one male each of $C$. batrachus and $C$. gariepinus that are sexually matured were obtained from the rearing tanks of Pisciculture laboratory, Centre for Cellular and Molecular Biology, Hyderabad, India. The females of $C$. batrachus and $C$. gariepinus were weighed and injected with a single dose of Ovaprim (Biomeda MTC, Canada) at the rate of $0.5 \mathrm{ml} / \mathrm{kg}$ body weight. The hormone was injected intramuscularly at an angle of $45^{\circ}$ to the body of fish in the region of the anal fin by using a $2-\mathrm{ml}$ hypodermic syringe fitted with B.D.H no. 22 needle. The females were allowed for a latency period of eight hours and fourteen hours in C. gariepinus and C. batrachus, respectively, at $26^{\circ} \mathrm{C}$. It is important to note that $\mathrm{C}$. batrachus brood stock was injected six hours earlier than $C$. gariepinus so as to synchronise the timing of ovulation and striping. Eggs from females were stripped into two separate bowls according to the species. Half of the eggs in each bowl were then transferred into another bowl using a rinsed chicken feather so as to have four set of eggs (two from each species) for the four directional crosses. A small portion of the unfertilized eggs (15-25 egg range) from both species were also isolated to serve as an indication of complete fertilization (this is by observing the time taken for the unfertilized eggs to become whitish). The males of both species were tranquilized with $150 \mathrm{mg} / 1$ solution of tricane methane sulphonate (MS222) (Wagner et al., 1997) before being sacrificed. The testes of the fish were removed and the sperm content macerated in two small bowls according to their species so as to mix the sperm content of both testes of the same species. Half of the content was then used to fertilize the eggs according to the direction of crosses shown below:

C. gariepinus $\hat{d} \times$ C. batrachus $q$ (Hby I)

C. gariepinus $q \times$ C. batrachus $\hat{\text { o }}$ (Hby II)

C. gariepinus $\hat{\delta} \times$ C. gariepinus $q(\mathrm{Cg}$ control)

C. batrachus $q \times$ C. batrachus $\hat{O}$. (Cb control)

After pouring the sperm content as appropriate into each batch of eggs, rinsed chicken feathers were used to mix the eggs and sperm uniformly for one minute, after which a small quantity of water $(100 \mathrm{ml})$ was added and the content mixed again for another minute. The excess water as well as the excess sperm were then decanted out of the small bowl leaving behind the fertilized eggs. The time taken for the small portion of the eggs initially separated to become opaque (dead eggs) was noted to estimate fertilization rate. Ella (1987) method was then used to estimate percentage fertilization according to the formulae stated below.

Hence, \% fertilization $=\frac{N-b}{N} \times 100$

Where $(\mathrm{N})$ represents the total number of eggs spawned (7000 eggs), (b) number of bad eggs and was obtained from the relation below;

$b=\frac{y}{x} \times N$

Where $(x)$ is the total number of eggs and $(y)$ is the number of bad eggs counted, Hence number of good eggs $(g)$ is denoted using: $N-b$

Triplicate batches of equal egg mass ( $10 \mathrm{~g}$ amounting to 7 000 eggs using the relation of 700 eggs in 1 gram mass of egg reported by Tiamiyu et al., 2015 for the same species) were incubated in a flow through system till hatching and yolk absorption were completed. A small portion of fertilized eggs ( $80 \pm 5.23$ numbers) were collected from each of the treatments and placed in different petri-dishes with water continuously aerated. These eggs were used to study the ontogeny development under a photomicroscope (Aluko, 1995; Olufeagba et al., 1999). The fertilized eggs were monitored from the point of fertilization to the time of hatching. Hatching rate was determined between 25 to 30 hours of fertilization and the number of hatchlings was taken by direct counting. The percentage of hatched larvae was determined using the ratio of dead eggs to hatch fry and expressing it as a percentage of total incubated egg number as shown below.

Hatching rate was calculated as:

$$
\frac{\text { no. of hatched larvae }}{\text { total no. of spawned eggs }} \times 100
$$

One hundred fry from each batch of eggs spawned for each treatment were then transferred into $60 \mathrm{~cm} \times 30 \mathrm{~cm}$ $x 30 \mathrm{~cm}$ glass aquaria tanks where they were raised for five months. Survival rate and morphological characteristics were recorded as observed at the end of the study. Fish were weighed on a two-digit analytical balance (Citizen Electronic).

\section{Cannibalism}

Cannibalism was estimated according to the method described by Solomon and Okomoda (2012) as follows: 
cannibalism mortality percentage was determined by observing the morphology of dead fishes for loss of body parts due to cannibalism. This observation was done every day when dead fish was seen in the culture chamber prior to feeding in the morning and evening. In addition, unobserved mortality was taken as though the fishes were completely cannibalized, except in cases of fish jumping out of the chamber, which was completely avoided during the study period. Hence, cannibalism mortality percentage was estimated using the formulae shown below.

$$
\text { Cannibalism mortality }=\frac{\begin{array}{c}
\text { Number of dead fishes with } \\
\text { missing parts } X 100
\end{array}}{\text { Total number of observed mortality }}
$$

\section{Morphological data}

Four morphological measurements were taken from the pure and hybrid crosses using methods described by Teugels et al. (1990). They include the number of anal fin ray, caudal fin ray, dorsal fin ray and total length $(\mathrm{cm})$. While total length measured was to determine the performance of fishes for growth (as subject to size variation), the meristic count was to indicate the pattern of morphological inheritance of the hybrids from their parents (note: meristic data are not affected by size variation).

\section{Data analysis}

Descriptive statistics were analyzed using minitab 14 computer software followed by one-way Analysis of Variance (ANOVA). Where significant differences are observed, means were separated using Fisher's least significant difference (at 95\% confidence interval).

\section{RESULTS}

All hatchlings in Hby II were observed with abnormalities and died few hours after hatching. Different deformities were identified in this treatment (Hby II). These included larvae with distorted head, bent tail, bent or wavy trunk, cephalic and rudimentary tail (Fig. B1-B4).

Normal hatchlings in $C$. batrachus and $C$. gariepinus both had straight body configuration, non-pigmented eyes and the head generally small and distinct from the "bulky" yolk. Crosses between C. gariepinus $\hat{f}$ and C. batrachus $q$ on the other hand produced a hybrid which developed traits and body coloration that are intermediate of the two parents (Fig. 2). Generally, they looked more like C. batrachus. Percentage hatchability, survival at $96 \mathrm{hrs}$ post fertilization and the number of deformed larvae along with the survival rate at five months of rearing are shown in Table 1 . The result obtained reveals better hatching performance of hybrids over their pure breeds. Morphological data collected also revealed (Table 2) higher growth performance for

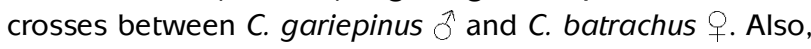
cannibalism was not observed in this treatment resulting in $100 \%$ survival of hatched larvae, however, dead fishes in control 1 had missing parts while some were unobserved mortalities.

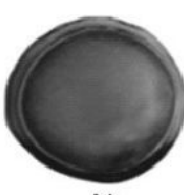

A1

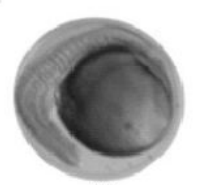

A3
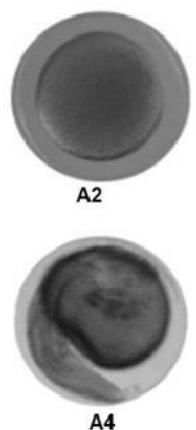

A4
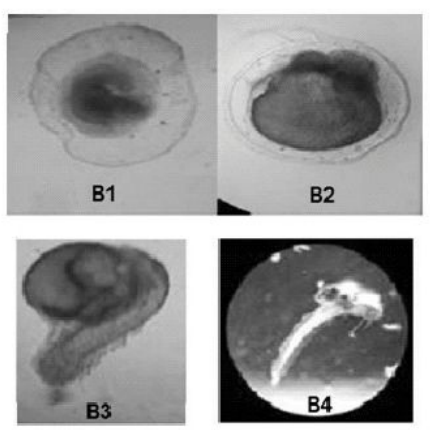

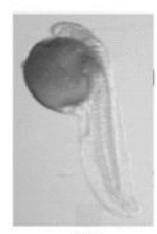

A5

Fig 1. Normally developing embryo until hatchlings of Hby $\mathrm{I}$ and pure breeds $(\mathrm{A} 1=$ egg, $\mathrm{A} 2=$ zygote, $\mathrm{A} 3=$ twenty-six somite cell, $\mathrm{A} 4=$ prime and $\mathrm{A} 5=$ normal hatched fry) and abnormally developing embryo until hatchlings Hby II (B1= unfertilized egg, B2= abnormal two cells stage, B3= abnormal hatchlings and B4= hatchling with spliced stomach) (photo taken during the present study)

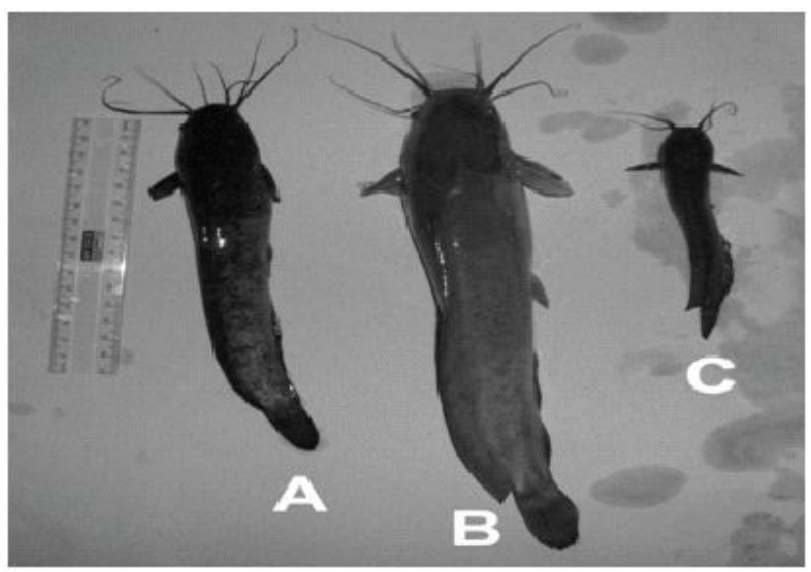

Fig 2. Nhotomacrograph of (A) Clarias gariepinus, (B) Hy II and (C) Clarias batrachus (photo taken during the present study) 
Table 1. Fertilization, hatchability, deformity and survival in Clarias gariepinus, Clarias batrachus and their hybrid

\begin{tabular}{|c|c|c|c|c|c|}
\hline & \%Fertilization & \%Hatchability & \%Survival & Deformed larvae (\%) & \% Survival (5 months) \\
\hline Hby I & $98.2 \pm 0.02^{\mathrm{a}}$ & $95 \pm 0.05^{\mathrm{a}}$ & $100 \pm 0.01^{\mathrm{a}}$ & $2.0 \pm 0.023^{b}$ & $100 \pm 0.01^{a}$ \\
\hline Hby II & $89 \pm 0.03^{b}$ & $85 \pm 0.12^{b}$ & $0 \pm 0.00^{c}$ & $100 \pm 0.04^{\mathrm{a}}$ & $0 \pm 0.02^{c}$ \\
\hline Cg control & $98.5 \pm 0.01^{\mathrm{a}}$ & $98 \pm 0.03^{a}$ & $95 \pm 0.12^{b}$ & $0.0 \pm 0.000^{b}$ & $75 \pm 0.23^{c}$ \\
\hline $\mathrm{Cb}$ control & $61.3 \pm 0.00^{c}$ & $50 \pm 0.02^{c}$ & $100 \pm 0.22^{\mathrm{a}}$ & $0 \pm 0.00^{b}$ & $90 \pm 0.03^{b}$ \\
\hline
\end{tabular}

Mean in the same column with different superscript differs significantly $(P>0.05)$

Table 2. Mean Morphological trait and cannibalism mortality in Clarias gariepinus, Clarias batrachus and their hybrid

\begin{tabular}{lcccccc}
\hline \hline & $\begin{array}{c}\text { Mean number of } \\
\text { anal fin ray }\end{array}$ & $\begin{array}{c}\text { Mean number } \\
\text { caudal fin ray }\end{array}$ & $\begin{array}{c}\text { Mean number of } \\
\text { dorsal fin ray }\end{array}$ & $\begin{array}{c}\text { mean total } \\
\text { length (cm }\end{array}$ & $\begin{array}{c}\text { Mean } \\
\text { weight (g) }\end{array}$ & $\begin{array}{c}\text { Cannibalism } \\
\text { mortality (\%) }\end{array}$ \\
\hline Hby I & $47.2 \pm 0.02^{\mathrm{a}}$ & $16.01 \pm 0.05^{\mathrm{a}}$ & $61 \pm 0.12^{\mathrm{c}}$ & $24.6 \pm 0.02^{\mathrm{a}}$ & $135 \pm 0.01^{\mathrm{a}}$ & $0.00 \pm 0.01$ \\
$\mathrm{Hby} \mathrm{II}$ & $*$ & $*$ & $*$ & $*$ & $*$ & $*$ \\
Cg control & $44.5 \pm 0.01^{\mathrm{b}}$ & $17.17 \pm 0.03^{\mathrm{a}}$ & $65 \pm 0.01^{\mathrm{b}}$ & $21.7 \pm 0.023^{\mathrm{b}}$ & $89.7 \pm 0.02^{\mathrm{b}}$ & $100 \pm 0.32$ \\
$\mathrm{Cb}$ control & $46.3 \pm 0.00^{\mathrm{a}}$ & $11.0 \pm 0.02^{\mathrm{b}}$ & $68 \pm 0.22^{\mathrm{a}}$ & $12.5 \pm 0.02^{\mathrm{c}}$ & $21.7 \pm 0.11^{\mathrm{c}}$ & $20 \pm 0.53$ \\
\hline \hline
\end{tabular}

${ }^{*}$ hatchling of the cross died hence could not be characterized morphologically; mean in the same column with different superscript differs significantly $(P<0.05)$

\section{DISCUSSION}

High fertilization rate was observed in this study probably due to the fact that the experiment was conducted at the peak of the rainy season when environmental factors were optimal (temp $\left.=26^{\circ} \mathrm{C}, \mathrm{DO}_{2}=5 \mathrm{mg} / \mathrm{l}\right)$. Hence, fish egg is expected to be of good quality at this time, being the peak of breeding season. Also, the hatchability rate of the pure and hybrid crosses of C. gariepinus was higher than ranges of 53.1-67.5\% reported in Ataguba et al. (2013) experiment where they administered copper sulphate as a prophylactic treatment for fungal control which was to encourage better hatching of the same species. Low level of deformities and mortalities were observed in $\mathrm{Cg}$ control as compared to $100 \%$ mortality observed in Hby II as a result of the deformities observed. Observation of the different deformities under the photomicroscope obviously pointed to the fact that the abnormal embryos may not survive. The blood flow could not get to all parts of the body because of sharp curvature in the body. Some of the abnormal embryos could not even swim at all due to distortions in their body structure. All the abnormal embryos died and this helped to avoid possible transmission of "aberrations" that may occur in their chromosome into the gene pool. Further work needs to be done to sequence the gene and study the deletion or addition that resulted in such phenotypes. Sahoo et al. (2003) and Rahman et al. (1995) reported similar observation in their report on hybridization between
C. gariepinus $q$ and C. batrachus $\hat{d}$. The authors reported mortality rate similar to the observations in this study and suggested that the mortality could be due to hybridization effect or chromosome incompatibility. Richter et al. (1995) and Sahoo et al. (2003) also reported total mortality in the cross of $C$. gariepinus $q$ and $C$. batrachus $\hat{\partial}$, and even in the reciprocal cross. Laywonyawut et al. (1992) and Sahoo et al. (2003) reported that the fry from the hybridization between C. macrocephalus $q$ and C.gariepinus $\hat{\delta}$ were not viable. Other authors like Mukhopadhyay and Dehadrai (1987) reported that total mortality occurred immediately after hatching in the hybridization of C. batrachus $\hat{o}$ and Heteropneustes fossilis 9 .

The expected excellent performance of hybrids over the purebreds as proposed by several researchers (Madu and Ita, 1991; Jantrarotai, 1993; Tober et al., 1995) was clearly confirmed in this work. The early growth performance of the hybrid clearly exceeded the performance obtained in the pure breed (Table 2). The mean weight reached after five months of rearing in the hybrid was similar to those reported by Rahman et al. (1995) for $C$. gariepinus $q$ and $C$. batrachus $\hat{d}$ during four-month culture period (representing Hby II in this present work which did not survive). Hecht and Uys (1997) had earlier pointed to the fact that cannibalism requires a lot of energy which otherwise could have been used for growth. Hence, reduction in growth performance of purebreds compared to the hybrids may be due to differences in cannibalism rate of the different genotypic 
groups. It is quite interesting that all the hatchlings in Hby I survived throughout the experimental period (5 months) and no cannibalism was observed. This could be a pointer to the possibility that the gene responsible for cannibalism in C. gariepinus may be recessive to that in C. batrachus. This is a great advantage and it will be a lucrative investment to produce the hybrid of $C$. gariepinus $\hat{o}$ and $C$. batrachus \%, especially in countries like Nigeria. The popular hybrid between $\mathrm{C}$. gariepinus and H. longifilis gives barely $55 \%$ of the number stocked at harvest time under the best rearing system due to the effect of cannibalism (Olufeagba et al., 1999). The performance of C. gariepinus $\delta$ and C. batrachus hybrid is heartwarming as it could replace other hybrids with growth advantage (heterosis), but high cannibalistic rate leads to discouraging and low yield by farmers at the time of harvest. Many of the dead fishes had characteristics similar to the mortalities described in Solomon and Okomoda (2012) experiment. Dead fish were observed missing either one or a combination of their barbels, eyes, fins, belly, tail and part or all of the body. Appelbaum and Mcgeer (1998) had also earlier attributed this mortality characteristic to cannibalism. Solomon and Okomoda (2012) had described prolonged darkness (24D: 00L) as a possible mechanism for reducing cannibalism in African catfishes. The result obtained in this study, however, provides a better option for cannibalism reduction through hybridization of African catfish with Asian catfish.

\section{CONCLUSIONS}

This study observed superior performance in growth and survival with reduced cannibalism for the hybrid between C. gariepinus $\hat{\delta} \times C$. batrachus $q$ when compared to their pure breeds. This superior performance could be exploited in commercial fish farms for better performance and higher revenue. The assumption made in this study that the gene responsible for cannibalism in C. gariepinus may be recessive to that in $C$. batrachus could be the focus of future research for validation. Further work also needs to be done to confirm and ascertain the cause of the total mortality observed in the $C$. gariepinus $q \times C$. batrachus $\hat{d}$ hybrid. However, future research can also focus on the aquaculture potentials of the hybrids, on the assumption that if hybrid gonads are viable, then the tetraploid of $C$. batrachus $q$ could be used to cross with $C$. gariepinus $\hat{f}$ to produce interploid hybrid which will take the advantage of the maternal heterosis arising from the tetraploid C. batrachus 9 .

\section{ACKNOWLEDGEMENTS}

Olufeagba S. O. is grateful to Third World Academy of Sciences and CSIR for the award of Post Doctoral Fellowship (CSIR-TWAS PDF 2007/2008). Authors are also thankful for the phenomenal contributions of the two anonymous reviewers of this manuscript.

\section{Sažetak}

\section{KANIBALIZAM I PROCJENA UČINKA HIBRIDA IZMEĐU Clarius batrachus i Clarius gariepinus}

Kanibalizam je važna karakteristika afričkog soma koja je značajno smanjila broj uzgojenih riba u ribnjačarstvima. Ova studija procjenjuje učinak uzajamne hibridizacije Clarius batrachus i Clarius gariepinus na kanibalizam i brzinu rasta njihovih potomaka u zatvorenom uzgojnom sustavu. Dobiveni rezultat ukazuje na odličnu performansu rasta hibrida $C$. gariepinus $\hat{o} \mathrm{i} C$. batrachus $q \mathrm{u}$ odnosu na izvorne vrste. Međutim, recipročni hibridi između C. gariepinus † i C. batrachus $\hat{\text { o }}$ ugibaju nekoliko sati nakon izlijeganja. Kanibalizam je značajno smanjen križanjem $C$. gariepinus đิ i C. batrachus 9 , sa $100 \%$-tnim preživljavanjem nakon pet mjeseci uzgoja. Rezultati istraživanja bi mogli koristiti uzgajivačima ribe pri komercijalnom uzgoju afričkog soma na smanjenje kanibalizma i povećanje uzgoja.

Ključne riječi: hibridizacija, afrički som, agresivno ponašanje, kanibalizam, azijski som

\section{REFERENCES}

Almazán Rueda, P. (2004): Towards assessment of welfare in African catfish, Clarias gariepinus: the first step. PhD dissertation, Wageningen University, Wageningen, The Netherlands.

Aluko, P. O. (1995): Growth characteristics of first, second and backcross generations of the hybrids between Heterobranchus longifilis and Clarias anguillaris. National Institute for Freshwater Fisheries Research Annual Report. New Bussa, Nigeria. $74-48$.

Appelbaum, S., McGeer J. C. (1998): Effect of diet and light regime on growth and survival of African catfish (Clarias gariepinus) larvae and early juveniles. Aquaculture Nutrition, 4, 157-164.

Ataguba, G. A., Annune, P. A., Ogbe, F. G. (2010): Growth performance of two African catfishes Clarias gariepinus and Heterobranchus longifilis and their hybrids in plastic aquaria. Livestock Research for Rural Development, 22.

Ataguba, G. A., Okomoda, V. T., Unde, E. S. (2013): Efficacy of Copper Sulphate as a Therapeutic Agent for Fungal Control on Egg, Hatching and Early Growth of Clarias Gariepinus (Burchell 1822). Asian Fisheries Science. 26, 156-166.

Boeuf, G., Le Bail, P. Y. (1999): Does light have an influence on fish growth? Aquaculture. 177, 129-152.

Ella, M. O. (1987): Simple calculations in fish farming. Wusen Press Ltd. Calabar, Nigeria. 64 pp.

Hecht, T., Uys, W. (1997): Effect of density on the feeding and aggressive behaviour in juvenile African catiish, Clarias gariepinus. South African Journal of Science 93, 
537-541.

Jantrarotai, W. (1993): Nutrients requirements of Thai walking catfish. NIFI Newsletter, 3, 2, 2-3.

Laywonyawut, K., Penman, D. J., Mc Andrew, B. J., Roongratri, N. (1992): Preliminary study on Karyotyping of the hybrid catfish Pla duk Big-oui (male C. gariepinus $\times$ female C. macrocephalus). In: Genetic in Aquaculture and Fisheries Management (ed. D.J. Penman, N. Roongratri and B.J. Mc Andrew), University of Stirling, UK, 141-142.

Legendre, M., Teugels, G. G., Cauty, C. Jalabert, B. (1992): A comparative study of morphology, growth rate and reproduction of Clarias gariepinus (Burchell, 1822). Heterobranchus longifilis Valenciennes, 1840 and their reciprocal hybrids (Pisces; Clariidae). Journal of fish Biology, 40, 59-79.

Madu, C. T., Ita, E. O. (1991): Comparative growth and survival of hatchlings of Clarias sp., Clarias hybrid and Heterobranchus sp. in the indoor hatchery. Annals Rep. National Institute for Freshwater Fisheries Research. (Nigeria). 47-50.

Mason, G. J. (1991): Stereotypes: a critical review. Animal Behaviour, 41, 1015-1037.

Mukhopadhyay, S. M., Dehadrai, P. V. (1987): Survival of hybrids between air-breathing catfishes Heteropneustes fossilis (Bloch) and Clarias batrachus (Linn.), Matsya, 1213, 162-164.

Olufeagba, S. O., Aluko, P. O., Omotosho J. S., Raji, A. (1999): Gonadal development and Growth performance of Laboratory Induced Triploid Catfish Heterobranchus longifilis. West African Journal of Biological Sciences, 10, 1, 76-83.

Rahman, M. A., Bhadra, A., Begum, N., Islam, M. S., Hussain, M. G. (1995): Production of hybrid vigor through crossbreeding between $C$. gariepinus (Bur) x C. batrachus (Linn). Aquaculture, 138, 125-130.

Richter, C. J., Eding, E. H., Ver Reith, J. J., Fleure, W. G.
(1995): African catfish (Clarias gariepinus): In broodstock management and Egg and Larval Quality. Eds Bromage and Roberts Published by Blackwell Science Ltd, London, 242- 276.

Sahoo, S. K, Giri, S. S., Sahu, A. K., Ayyappan, S. (2003): Experimental hybridization between catfish $C$. gariepinus (Bur.) and C. batrachus (Linn) and performance of the offspring in rearing operations. Asian Fisheries Science, 16, 157-166.

Solomon, S. G., Okomoda, V. T. (2012): Growth response and aggressive behaviour of Clarias gariepinus fingerlings reared at different photoperiods in a water re-circulatory system. Livestock Research for Rural Development, 24, 191.

Teugels, G. G. (1986): A systematic revision of the African species of the genus Clarias (Pisces. Clariidae). Annales du Musée Royal de l'Afrique Centrale, 247. 1-199.

Teugels, G. G., Denayer, T., Legendre U. (1990): A systematic revision of the African catfish genus Heterobranchus Geoffrey Saint Hillarie, 1809 (Pisces: Clariidae). Zoological Journal of the Linnean Society, 98, 237-257.

Tiamiyu, L. O., Okomoda V. T., Oyeniyi M. E., Aperegh J. K. (2015): Spawning performance of Clarias gariepinus administered serially diluted doses of ovaprim. Banat's Journal of Biotechnology, 11, 30-35.

Tober, B., Gabriele, H., Hans-Jurgen, L. (1995): Species crosses in African catfish Clarias gariepinus x Heterobranchus longifilis. Aquaculture, 137, 325-332.

Wagner, E. J., Jensen, T., Arndt, R., Routedge, M. D., Brddwisch, Q. (1997): Effects of rearing density upon cut throat trout haematology, hatchery performance, fin erosion and general health and condition. The Progressive Fish-Culturist, 59, 173-187. 